REVISTA ARA N8. VOLUME 8 . OUTONO+INVERNO 2020 • GRUPO MUSEU/PATRIMÔNIO FAU-USP

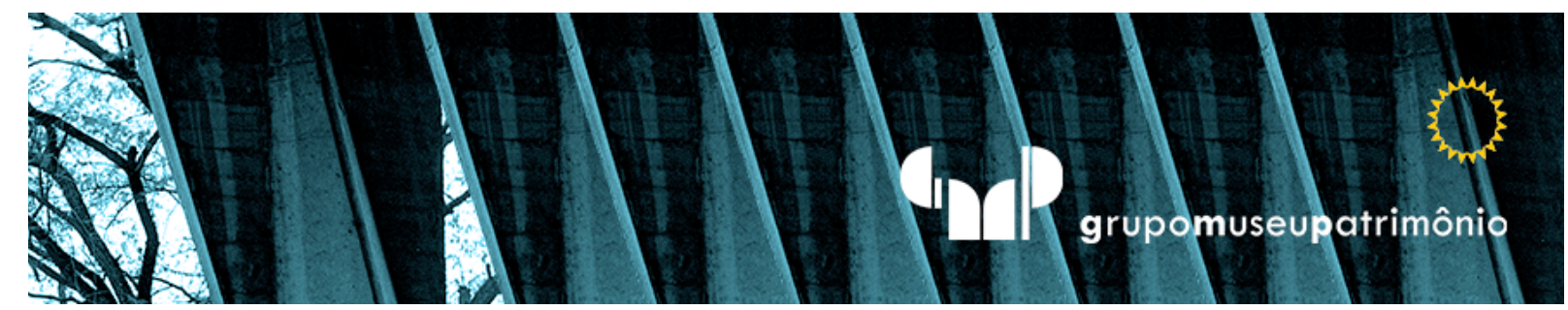

Editorial

\title{
Aparência e aparição
}

\author{
Apariencia e aparición
}

\section{Appearance and apparition}

\begin{abstract}
Maria Cecília França Lourenço
Professora Doutora Titular Sênior da Faculdade de Arquitetura e Urbanismo Universidade de São Paulo, São Paulo, Brasil, mcfloure@usp.br

\section{Luiz Recaman}

Professor Livre-docente da Faculdade de Arquitetura e Urbanismo Universidade de São Paulo, São Paulo, Brasil, recaman@usp.br

Anna Maria Rahme

Professora Doutora Pesquisadora no Grupo Museu/Patrimônio da FAUUSP, São Paulo, Brasil, annarahme@gmail.com
\end{abstract}




\section{EDITORIAL}

A aparência é enganadora, falsa, ela supõe o simulacro. Já a aparição é um evento autêntico, impossível de ser reduzido: é um raio que corta o céu (DIDI-HUBERMAN, 2017, ZUM \# 13).

$\mathbf{E}$ sta edição da Revista ARA FAU USP marca inúmeras inflexões, vitórias e se mostra uma aparição na cena confinada a que a aparência do mundo se reduz nessa hora. A distinção entre aparição e aparência foi formulada por Georges Didi-Huberman em entrevista elaborada por Lúcia Ramos Monteiro ao site da Revista ZUM, por ocasião da exposição "Levante".

O historiador e filósofo defende a ação de levante/aparições e reitera crítica presente em tantos de seus estudos, relativos à mutação da imagem em mero espetáculo, eivado por aparência. Defende que na política tudo se torne visível e não apenas simulacro, antes mesmo da pandemia, nomeada por Covid-19, instalar-se em escala global e mundial em que fake news inundam o cotidiano.

Vários entre os textos aqui reunidos, embora entregues antes das primeiras mortes na pandemia, se valem dos aportes à cultura tanto de Didi-Huberman, o diálogo dele, como de outros, com Walter Benjamin na questão da aura e 
suas consequências; quanto de Jacques Rancière sobre a partilha do sensível; Giorgio Agamben na relação com a contemporaneidade e a atualização sobre o que Michel Foucault denominou por dispositivos de controle.

Outros clássicos do pensamento atual comparecem em estudos desta edição, constituindo-se em excelente bagagem para refletir sobre os tempos atuais. Cite-se Hans Robert Jauss, sobre a ampliação de horizontes efetuada pela recepção das obras; Maurice Merleau-Ponty, nas questões perceptivas e epistemológicas; Jean Baudrillard, ante à multiplicidade de imagens e ao conceituar simulacros; Marc Augé, na diferenciação entre lugar e não-lugar; Hal Foster na crítica à maré conservadora; Oliver Grau sobre inteligência artificial e a falácia da imersão no virtual, entre outros.

Acrescente-se algo singular, ou seja, análises relativas aos filmes, instalações, arquitetura, cidade e obras contemporâneas ou de vanguarda como a de Lina Bo, a envolver muitos dos estudiosos já mencionados. A recepção das obras e a representação constituem também valioso cabedal. Nessa hora de se rever certezas, conceitos formulados e problematizados podem colaborar para descortinar futuro, se não melhor, ao menos mais essencial, social e humano em variadas áreas e latitudes.

No geral, os artigos buscam tensionar a imagem para que essas possam ajudar elucidar ou superar os impasses culturais e sociais de um mundo que drasticamente se desespetaculariza. Nosso outro fin de siècle construído por simulacros delirantes, que deram intangibilidade a um mundo que agora reclama a mais crua realidade. Alguns autores desta edição buscam no rastros de artistas tão variados como Bruce Nauman, Anthony McCall, Basel Abbas e Ruanne Abou-Rahme, Lina Bo, Laís Myrrha, Alain Resnais, Harun Farocki mirando Sauerbruch Hutton Arquitetos e Andreas Gursky encontrar essas possibilidades críticas. Completando a tríade pensamento/obra/percepção, apresentamos também ensaios visuais do percurso entre as estações Luz e São Bento (SP) e do grupo Devaneios experimentais e poéticas narrativas. 
"Imagem e Deslocamento" provocação proposta e, também, bem apresentada por Ricardo Fabbrini nesta oitava edição da Revista ARA, teve uma dupla qualidade atestada pela diversidade em contribuições: um campo semântico que orbita em uma determinada e coerente série de autores fundamentais; e, ao mesmo tempo, estimula abertura crítica para o enfrentamento de realidades contemporâneas, diversas e multifacetadas. Dessa maneira, agrega todo incomum, com muitas reflexões e entre-espaços, estes entendidos como propõem inúmeros pensadores. Ainda que se alinhem distintas palavras, aponta-se para o vivido pelo humano, a vida em diferentes situações e relações.

O Conselho Editorial/CE igualmente desempenha papel essencial para examinar, formular política editorial, caminhos e indicação para parecer. Ao contrário da polarização evidenciada em inúmeras esferas, CE e GMP realizam ação harmônica e distante de disputas de poder, disseminadas na atualidade. Com enorme satisfação resolvemos alternar a Editoria da Revista ARA FAU USP, assumindo Luiz Recamán, que por certo muito contribuirá.

Devido ao grande número de artigos aprovados que discutiram a chamada da revista, o Conselho Editorial decidiu que o tema da ARA 8 seria constituído em duas edições no próximo número. Assim, estamos apresentando também a ARA 9, que contém os artigos para essa mesma chamada "Imagem e Deslocamento". Essa decisão se deu no contexto das dificuldades enfrentadas por todos no atual momento, para o qual pretende contribuir.

Boa leitura!!! 